\title{
Arabiske oprør har hver deres unikke baggrund
}

\section{Steffen Jensen}

\section{Reflektioner over det arabiske forår til lyden af missiler i Libyen. Også den israelsk-palæstinen- siske konflikt påvirkes, men ingen af parterne synes at tage ved lære}

\section{"Izzzzzzzzuuuuiiiit!"}

Man hører bare lige den skarpe, hvissssslende lyd, alle kaster sig ned i støvet, og et sekund senere kommer drønet, som får indvoldene til at ryste lidt rundt i kroppen. Og er man heldig, rejser alle sig op igen. Det er vi. Indtil videre i hvert fald. Men Grad-missiler kommer igen og igen susende hen over vore hoveder og eksploderer med et øredøvende brag, som næsten sprænger trommehinderne. De er ved at skyde sig ind på os, de Gaddafi-loyale regeringstropper, som ligger gravet ned en 4-5 km længere fremme ad hovedvejen vestpå... mod Tripoli. Missilerne er nu kun omkring 20-30 meter fra os og den gruppe oprørere, som kontrollerer det vejkryds, vi befinder os $\mathrm{i}$.

"Allah hu-Akhba", råber oprørerne, hver gang en granat lander. In- gen af dem gør mine til at gå i dækning. Nogle er ved at lave kaffe på et lille bål, et par andre sidder og spiller skak og alle ryger de som skorstene uafbrudt. Hvad betyder faren ved rygning, når man kan blive dræbt af en granat inden dagen er omme?

"Izzzzzzzzuuuuiiiit... ...buuuum!"

Jeg sidder i skyggen foran et udbombet kaffehus i Dafniya, en lille landsby uden for den belejrede libyske by Misurata, omkring $180 \mathrm{~km}$ fra Tripoli, og skriver på denne artikel, mens min fotograf Rasmus Nielsen har stillet vores transportable satellit-uplink op på taget af bilen, og er i færd med at sende dagens indslag hjem til TV2/Nyhederne.

\section{Welcome to Libya}

"Ahalan va-Sahalan - Welcome to Libya”, siger en ung dreng på 18-19 år 
på gebrokkent engelsk. Han smider sit gamle belgisk producerede 7,62 mm FN-maskingevær på jorden og sætter sig ved siden af mig.

"How are you? Er det dit første besøg i Misurata”, spørger han.

Jeg nikker. Han er så ung, at det skæg, han forsøger at anlægge for at ligne en rigtig hellig kriger, kun er nogle krøllede dun på hagen. Men han har allerede kæmpet imod Gaddafis soldater i tre måneder. Som alle andre vil han vide, hvad jeg tænker, og hvor lang tid, jeg giver Muammar Gaddafi.

"You are from the outside. You know stuff", siger han med tilstræbt amerikansk accent. Han har aldrig været uden for Libyen. "Er Gaddafi ved at vælte? Vi hører, at den amerikanske udenrigsminister forhandler med folk i hans inderkreds. Hvad siger du?"

"Det kan også være psykologisk krigsførelse", svarer jeg. "For at få Gaddafis styrker længere oppe ad vejen til at frygte, at han er på vej til at forråde dem bag deres ryg."

Han nikker og tænker lidt over det: "Så bliver vi sikkert nødt til at kæmpe os frem hele vejen til Tripoli”, siger han uden at fortrække en mine. "Men det kan tage lang tid."

Oprørerne her i Misurata-området har været belejret af regeringsstyrkerne i månedsvis, og er konstant under bombardement af Gaddafis tunge artilleri og Grad-raketter. Alligevel synes de underligt opstemte og sejrssikre.
I de seneste måneder har oprørerne i Misurata kæmpet en indædt kamp for ikke at blive løbet over ende af regeringsstyrkerne, som både i udrustning og træning er dem langt overlegne. Oprørsstyrkernes eneste fordel - måske i virkeligheden deres hemmelige våben - er deres motivation og visheden om, at deres alternativer er til at overskue. Enten vinder de, eller så dør de. Ingen tror, at de har en chance for at overleve, hvis de bliver taget til fange eller kapitulerer.

"Izzzzzzzzuuuuiiiit... ...buuuum!"

Det er ikke bare lyden af Gaddafistyrkernes granater, der pifter ind over hovederne og eksploderer. Det er også på en vis måde lyden af Det Arabiske Forår. Den lyd foråret har fået her i Libyen.

\section{Undtagelser som Sydsudan}

Libyen er blot en af de mange skuepladser, hvor Det Arabiske Forår i øjeblikket udspiller sig. Tunesien, Egypten, Syrien, Bahrain og Yemen er andre. Marokko har valgt en mere lempelig linje, som også er udløst af uroen i regionen; og den mulige forsoning mellem palæstinensernes rivaliserende Hamas- og Fatah-bevægelser hænger også sammen med det. Der er absolut grøde i den mange steder i Mellemøsten i øjeblikket. Ikke alle steder skyldes uroen og ændringerne nødvendigvis Det Arabiske Forår i lige og direkte forstand. For eksempel Sydsudan som 
lige er blevet udråbt som en uafhængig stat. Men den politiske dynamik i hele regionen har givetvis også indflydelse på, hvordan tingene udvikler sig i Sudan. Der er også spændinger i Libanon, som har fået en Hizbollah-kontrolleret regering, mens FN nogenlunde samtidigt har udpeget fire Hizbollah-medlemmer som skyldige i mordet på tidligere premierminister Rafiq Hariri i 2005.

Her er der heller ikke nogen direkte forbindelse, men begivenhederne omkring dem spiller alligevel ind, og de unges krav om anstændig regeringsførelse og respekt for loven andre steder i Mellemøsten registreres også af Libanons unge. Desuden vil de sammenstød, der i øjeblikket finder sted i Syrien, som alt andet hos den store nabo altid få betydning for udviklingen i Libanon.

Irans præsident Mahmoud Ahmadinejad er under pres både fra den åndelige leder Ali Khamenei og også fra sit eget bagland i Revolutionsgarden. Det er heller ikke umiddelbart forbundet med Det Arabiske Forår, og alligevel vil begge dele påvirke hinanden. Og på den måde kunne man blive ved.

Hvad er det så der sker, og hvorfor sker det?

Dramatiske historiske begivenheder som revolutioner, opstande og borgerkrige har det altid med at blive personificeret med en enkelt 'helt' eller identificeret med en specifik begivenhed. Det skyldes sikkert både menneskelig natur og aktivist- ernes behov for et symbol, der kan bruges til at samle folk om banneret og sagen, men det skyldes formentlig også os i medierne, som elsker at kunne sætte ansigter og skæbner på alt.

Derfor kunne jeg naturligvis godt give en malende beskrivelse af den frustrerede, unge tunesiske grønthandler Mohamed Bouazizi, som havde fået nok og brændte sig selv ihjel i protest imod en lokal politibetjent, der konfiskerede hans grøntsagsbod i byen Sidi Bouzid $300 \mathrm{~km}$ syd for Tunis, og dermed uden at vide det blev gnisten, der fik den tunesiske revolution til at eksplodere. Eller Khaled Said, der efter en aften $i$ byen med nogle venner i den egyptiske middelhavsby Alexandria uvist hvorfor blev arresteret af politiet og tævet ihjel i en trappeopgang. Hans død bliver kendt igennem Facebookgruppen 'We are all Khaled Said', hvorefter han blev et af den egyptiske revolutions samlende symboler.

\section{Ligheder og unikke grunde}

Men det vil jeg dog ikke. For begivenhederne er ikke begrundelsen for revolutionerne i hverken Tunesien eller Egypten. De var maksimalt den gnist, der fik de allerede fyldte krudttønder af vrede og frustration til at eksplodere. Men som symboler var Mohamed Bouazizi og Khaled Said brugbare både for aktivister og journalister, så mange tror, at revolutionerne i Mellemøsten skyldes dem. 
På overfladen er mange af årsagerne, utilfredsheden og vreden fælles i de arabiske lande, som oplevede demonstrationer, væbnede sammenstød og omvæltninger. Men fokuserer man kun på disse ligheder, mister man fornemmelsen for alle de unikke grunde, der også er i hvert af de samfund, der er blevet fejet med af Det Arabiske Forår.

Det forår, der begyndte i Tunesien, hvor de daglige optøjer og demonstrationer ret tidligt førte til præsident Zein el-Abedine Ben Alis uværdige flugt først til Frankrig, som vendte ham ryggen, og derefter til Saudi-Arabien. Det fik det til at løbe koldt ned ad ryggen på mangen arabisk diktator. Især da uroen bredte sig som en ørkenstorm fra land til land. Egypten, Libyen, Bahrain, Yemen og Syrien. Der er i dag næppe en mellemøstlig præsident, konge, emir, militærdiktator eller autokrat, som ikke i øjeblikket har daglige møder med sine sikkerhedschefer, rådgivere og sammensvorne, for at finde ud af, hvordan de skal ride stormen af, samtidig med at de bare for en sikkerheds skyld fors $\emptyset$ ger at flytte deres værdier til sikre bankkonti rundt i verden, hvor der ikke stilles ubehagelige spørgsmål om, hvor pengene stammer fra.

I Egypten bliver den tidligere præsident Hosni Mubarak og hans to sønner snart stillet for retten, hvis Mubarak ikke bukker under inden for den cancer, hans forsvarsadvokat påstår, at han lider af. Landets præ- sident igennem tre årtier kan risikere at blive dødsdømt, hvis anklagemyndigheden formår at bevise, at ordren til at bruge dødelig vold imod demonstranterne kom fra ham.

Libyen er indtil videre reelt blevet delt i to. En østlig del som effektivt er på oprørernes hænder, mens det vestlige Libyen fortsat kontrolleres af en stadigt mere utilregnelig oberst Muammar Gaddafi. Libyen befinder sig i en reel borgerkrig mellem en utrænet, amatøragtig men højtmotiveret oprørshær, der dog næppe ville have en chance, hvis NATO ikke bombarderede Gaddafis militær fra luften. Det Nationale Overgangsråd, som den provisoriske oprørsregering officielt hedder, er ved at løbe tør for penge, og med mindre der snart findes en international politisk løsning på oprørernes finansielle problemer, kan revolutionen bryde sammen, inden den har nået sit mål.

\section{Syrien - langsom massakre}

Syrien befinder sig midt i en langsom, rullende massakre på befolkningen, som uanset den brutale vold synes at slutte op om opstanden i stadigt større tal. Præsident Bashar al-Assad, hvis familie har kontrolleret landet i 40 år, synes ubøjelig. Mange siger, at hans styre, som i en vis udstrækning baserer sig på landets alawitiske minoritet, frygter, at de ikke kun kæmper for deres politi- 
ske magt, men også for deres egen fysiske overlevelse, og derfor ikke ser nogen mulighed for forsoning og kompromis. Den nationale dialog, regimet netop har indledt, er der ikke mange af de unge aktivister der tror på, selvom nogle gamle oppositionspolitikere deltager i den.

I Yemen har præsident Ali Abdullah Saleh overlevet et attentat, men befinder sig på et saudiarabisk hospital, hvorfra der kommer modstridende oplysninger. Hans eget regime siger, at han vil vende tilbage til Yemen i løbet af kort tid og genindtage præsidentposten. Saudierne synes at mene, at præsidenten er langt hårdere medtaget, og har brug for en mere langstrakt medicinsk behandling. Om Saleh faktisk kun er til hospitalsbehandling eller er i en form for medicinsk semi-husarrest, fordi saudierne vil gennemtvinge en magtoverdragelse i Yemen, er uklart.

På østaten Bahrain er det sunnierne, der udgør minoritetsstyret omkring Khalifa-familien. Her kæmper det shi'itiske befolkningsflertal sammen med moderne og mere liberalt indstillede sunnier for også at få del i vore vestlige liberale frihedsidealer. Noget kongefamilien hidtil med held har afværget. Og den holder sig fortsat ved magten med hjælp fra politi og sikkerhedsstyrker, som for en stor dels vedkommende består af jordanere, pakistanere og andre udlændinge, fordi regimet ikke stoler på sin egen shi'itiske befolkning. Når det går rigtig hedt til, sender
Saudi-Arabien sine egne sikkerhedsstyrker i panservogne over til øen for at stive kongen af.

Det ulmer også i en lang række andre arabiske stater. Der har været demonstrationer i Jordan. Libanon er heller ikke stabilt, om end utilfredsheden her har andre rødder. Algeriet og Marokko har også haft sine demonstrationer. Den marokkanske kong Mohammed VI forsøger sig med en fredelig dialog, sindige liberaliseringer og en ny, lidt mere demokratisk forfatning.

\section{Som Berlinmurens fald}

Uanset hvordan det ender, vil året 2011 gå over i historiebøgerne. Intet vil være det samme, når støvet lægger sig. Vi er oppe på niveau med Den Islamiske Revolution i Iran i 1979, Seksdageskrigen i 1967 eller Israels oprettelse og det palæstinensiske flygtningeproblems opståen i 1948. Det er ikke uden grund, at mange analytikere og kommentatorer siger, at de dramatiske begivenheder er på niveau med 'Berlinmurens fald' på arabisk. Det vil dog være naivt at tro, at den arabiske verden er blevet fuld af demokratier, når der igen falder ro over regionen.

Hvis blot nogle af de arabiske lande, når røgen letter, er kommet 'på rette vej' med kurs mod mere frihed og folkelig medindflydelse, vil Det Arabiske Forår kunne kaldes en kæmpemæssig succes. Men der vil 
under alle omstændigheder være tale om et mentalt-politisk jordskælv af dimensioner i en region, som indtil for kort tid siden syntes upåvirkelig og totalt immun over for frihed, demokrati og respekt for menneskerettighederne.

Vi har også en tendens til at omtale alle uroligheder og demonstrationer i den arabiske verden i disse måneder som en del af Det Arabiske Forår, som en del af den samme bølge af vrede og frustrationer, som om demonstranterne fra Tunis til Sana'a er en del af et fælles oprør med ens årsager, samme mål, og inspireret af en fælles ideologi. Det er langtfra tilfældet.

Der er næppe nogen tvivl om at samtidigheden betyder, at den ene opstand rent taktisk og teknisk er blevet inspireret af den anden. Men der er lige så mange årsager og forudsætninger, der skiller de forskellige oprør, som der er forhold, der forener dem. Og disse forskellige rødder og forudsætninger betyder også, at landenes chancer for at nå de mål, demonstranterne drømmer $\mathrm{om}$, er ligeså forskellige.

Tuneserne er stort set en nation af rimeligt veluddannede middelklasseborgere, som for en meget stor dels vedkommende er ret vestligt orienterede. Befolkningen er forholdsvis homogen, og tilhører samme, rimeligt moderate udgave af islam. Trods sine mangler og myndighedernes løbske korruption var det tunesiske samfund også inden revo- lutionen ganske velorganiseret. Omkring 80 procent af befolkningen ejer deres eget hus.

\section{Egypten uden for Kairo}

Egypten er en kæmpemæssig nation, hvor størstedelen er fattige med en meget sparsom skolegang bag sig, ofte meget fromme muslimer, og selvom vi i omverdenen er rimeligt velinformerede om revolutionen på Tahrirpladsen i Kairo, er der mange egyptere i landsbyerne i deltaet eller i Øvre Egypten, som ikke har oplevet mærkbare forandringer, og det lidt de ved om begivenhederne i Kairo, hører de fra de aktivister fra Det Muslimske Broderskab, som er langt mere aktive i landdistrikterne og fattigkvartererne i storbyerne, end de unge, moderne reformaktivister, der faktisk stod for den egyptiske revolution.

I modsætning til Egypten, som har en distinkt national identitet, der strækker sig årtusinder tilbage i historien, er Libyen en relativ ny nationalstat med en befolkning, der baserer sig på stammer, hvis oprindelse er nomadestammer fra ørkenen. Et stammesystem, som kunne være gradvist forsvundet i takt med urbaniseringen, men som Gaddafi holdt i live i en del og hersk politik.

Og mens både Tunesien og Egypten har relativt veludviklede civilsamfund i betydningen af organisationer, fagforeninger og meget andet (med alle de begrænsninger der 
naturligvis følger af at fungere i et ikke-demokratisk samfund), så mangler Libyen fuldstændig denne form for organisering af befolkningen.

I Tunesien er det gamle system næsten blevet luget ud, så befolkningen nu skal til at bygge nye strukturer op fra grunden. Mens Egypten nu ikke ledes af de revolutionære, men tværtimod af militæret, som var en integreret del af det regime, der angiveligt skulle være væltet. Og libyerne, når de kommer til det punkt, hvor Gaddafi er forsvundet, skal lappe landet sammen efter en blodig borgerkrig.

Mens militæret stillede sig på befolkningens side i Tunesien, og ikke har tradition for at spille nogen større politisk rolle, så er de væbnede styrker i Egypten en enorm politisk og økonomisk magtfaktor, og selvom de officielt har stillet sig på befolkningens side og ubestrideligt har været en stabiliserende faktor midt i omvæltningen, så er det stadigvæk et åbent spørgsmål, om det egyptiske militær har forsøgt at beskytte så stor en del af det gamle system som muligt eller blot sine egne investeringer, økonomiske interesser og politiske indflydelse snarere end ærligt at dele demonstranternes ønske om grundlæggende og gennemgribende at reformere det egyptiske samfund.

Og helt anderledes forholder det sig naturligvis med de militære styrkers rolle i Libyen og Syrien. I Liby- en har store dele af de væbnede styrker skiftet side og kæmper nu sammen med oprørerne. I Syrien er militæret fortsat rimeligt loyalt over for regimet, og oprørerne har ikke haft held til at erobre et egentligt landområde endsige etablere en egentlig oprørsledelse.

Og sådan kunne man blive ved land for land med at fremhæve lige så mange forskelle som ligheder.

\section{Israel og Palæstina}

Andre araberes kamp har brudt palæstinensernes monopol på de internationale mediers opmærksomhed. Og Israel er langsomt (for langsomt formentlig) ved at indse, at landet i Washington ikke længere udelukkende ses som en strategisk gevinst i Mellemøsten, men i stigende grad i visse situationer også opfattes som en byrde. I en række krisesituationer i Mellemøsten fra Golfkrigen i 1990-91 og frem har Israel ikke kunnet assistere USA. Tværtimod har en israelsk medvirken kunnet sabotere USA's og Vestens forhold til de vestvendte arabiske lande - som vi fejlagtigt har en tendens til at kalde 'moderate' - der i de pågældende situationer har været mere brugbare for Vesten i forsøgene på at løse konflikterne.

Ud over den bratte opvågning til denne nye virkelighed så præsenterer bølgen af revolutioner og systemkritiske optøjer, som lige nu skyller hen over den arabiske ver- 
den, naturligvis også Israel - men også palæstinenserne - for en hel række nye, umiddelbare problemer og udfordringer.

På ét niveau er Israel forståeligt nok bekymret for de fredsaftaler, landet har med de umiddelbare naboer Egypten og Jordan. Men Israel følger også nøje situationen i Syrien, som ikke bare er afgørende for stabiliteten langs våbenhvilelinjerne i Golan Højderne, men som også spiller afgørende ind på det, der sker i Libanon. Og ikke mindst følger Israel med i, hvordan Iran ude på sidelinjen stille og roligt øger sin indflydelse i et Mellemøsten, hvor det ene arabiske regime efter det andet synes at vakle, og hvor USA's og Vestens indflydelse ikke længere er en given ting.

Ved det egyptiske valg til september får vi at se, om Det Muslimske Broderskab får en så fremtrædende plads i en kommende regering, som det lige nu kunne tyde på. Sker det, frygter Israel både for fredsaftalen og for Egyptens fremtidige politik over for Hamas i Gaza Striben.

En ny meningsmåling i Egypten viser imidlertid, at omkring to tredjedele af egypterne ønsker at bevare fredsaftalen med Israel, mens 'kun' 11 procent vil have den ophævet. Man skal dog ikke altid tage den slags meningsmålinger alvorligt $\mathrm{i}$ denne del af verden. Der er også meningsmålinger der viser, at et stort flertal vil have en pluralistisk, demokratisk stat. Og samtidig vil et stort flertal også have en lovgivning baseret på den islamiske sharialov. Jordan er endnu forholdsvis rolig. Men den ulmende utilfredshed i landet i mange år synes i lyset af uroen i resten af regionen nu endnu mere truende set fra Jerusalem. Og landet grænser op til Vestbredden, samtidig med at størsteparten af Jordans befolkning er palæstinensisk, så trues kong Abdullahs styre, kan det blive problematisk for Israel. Trues roen og stabiliteten i Jordan, bliver israelerne mindre tilbøjelige til at forhandle om Vestbreddens fremtid som en del af eventuel palæstinensisk stat. For vakler Jordan, så begynder Vestbredden for mange israelere igen at ligne en strategisk nødvendighed som buffer østover.

\section{Israel og Syrien}

Selvom den syriske præsident Bashar al-Assad absolut ikke vækker nogen varme følelser i Jerusalem, har både han og hans far i 40 år i det mindste været noget af en konstant, som israelerne kunne kalkulere med. Vælter han, eller vakler hans regime, og tvinges han dermed endnu mere i armene på Iran, kan det få alvorlige konsekvenser for sikkerheden i det nordlige Israel. Både langs våbenhvilelinjen i Golan Højderne ind mod Syrien, men også langs grænsen til det sydlige Libanon, hvor den shi'a-muslimske milits Hizbollah, som støttes af Syrien 
og finansieres, udrustes og trænes af Iran, har den reelle kontrol - trods tilstedeværelsen af en 12-14.000 mand stor FN-styrke og libanesiske regeringssoldater.

Roen langs Golan- og Libanongrænsen er, set fra Jerusalem, et håndtag, som lederne i Damaskus bruger til at skrue op og ned for efter behag. Det fik Israel en forsmag på i maj. Hvert år markerer palæstinenserne 'Den store Katastrofe' An Naqba - den 15. maj, dagen hvor Israel blev oprettet i 1948. I år lykkedes det underligt nok for tusindvis af palæstinensiske og syriske demonstranter at begive sig igennem de syriske militære linjer i Golan Højderne - en af de mest militariserede dele af Syrien - igennem grænsehegnet, igennem minefeltet, igennem FN-styrkens ingen-mands-land og igennem det israelske grænsehegn, hvorefter de blev mødt af israelske militære styrker, som skød og dræbte flere. Nøjagtig det samme udspillede sig langs grænsen til det Hizbollah-kontrollerede Syibanon. Hele setup'et gentog sig i Golan måneden efter An-Naqsa-dagen, palæstinensernes markering af nederlaget i '67-krigen.

Hvad Det Arabiske Forår fører til på den palæstinensiske side, får naturligvis også konsekvenser for Israel.

\section{Palæstinensisk kompromis}

Urolighederne i Syrien påvirker Hamas, der har sit politiske hovedkvar- ter i Damaskus. Og Khaled Mashal, organisationens politiske generalsekretær, er blevet endnu stærkere internt i bevægelsen, fordi det også er ad denne vej, Iran kanaliserer sin ganske betydelige finansielle hjælp til Hamas. Frygten for den fremtidige stabilitet i Syrien var uden tvivl en vigtig grund til, at Hamas efter et par års afvisning pludselige ønskede en politisk kompromisløsning med ærkerivalerne i Fatah. En anden grund var, at omvæltningerne i Egypten havde fjernet Hosni Mubarak, som hadede Hamas, og bragte mere samarbejdsvillige og Israel-kritiske folk ind på ledende poster. Derfor blev Egyptens rolle som mægler mellem Hamas og Fatah betydeligt styrket.

Så Det Arabiske Forår har allerede ført til en forsoningsaftale mellem de to rivaliserende palæstinensiske bevægelser og et løfte om, at de vil danne en samlingsregering til at føre det palæstinensiske samfund frem til et valg, så palæstinenserne igen kan få en legitim regering og tale med én stemme. Men trods alle smukke ord så synes forsoningen ikke at være blevet til meget mere end det-smukke ord.

På Fatah-siden fik Det Arabiske Forår straks præsident Mahmoud Abbas til at tale om nye valg. Hans egen præsidentperiode udløb for flere år siden. Da forhandlingerne med Israel har været kørt uhjælpeligt fast siden Benyamin Netanyahu rykkede ind i premierministerens 
kontor, førte det til en ny palæstinensisk strategi. Kunne man ikke opnå en tilfredsstillende løsning med Israel, så kunne man unilateralt forberede den palæstinensiske stat, $\mathrm{og}$ så bede resten af verden om at anerkende den - uden om Israel. Men med de tilsyneladende nye demokratiske vinde, der var begyndt at blæse i den arabiske verden, og de forventninger, det udløste i Vesten, blev et valg og en vis form for legitimitet en nødvendighed. Så det proklamerede præsident Abbas.

Det seneste er dog, at den palæstinensiske præsident nu har meddelt, at der hverken kommer en palæstinensisk samlingsregering eller noget valg inden september, hvor palæstinenserne efter planen vil forsøge at få $\mathrm{FN}$ og resten af verden til at anerkende den palæstinensiske stat.

Det er dog i forhold til palæstinenserne værd at huske på, at de allerede har været der, hvor de moderne, veluddannede unge i de arabiske lande, som ønsker frie, demokratiske valg, bare kan drømme om at nå til. Palæstinenserne er faktisk det eneste arabiske folk, der allerede har gennemtvunget et politisk systemskifte - ikke ved et militærkup, men ved et frit, demokratisk valg. Det skete i 2005, hvor palæstinenserne efter årtier med Fatahs og PLO's misrøgt og korruption satte de traditionelle magthavere på porten og valgte islamisterne i Hamas. Formentlig mere på grund af Hamas' løfter om ren regeringsførelse og is- lamisk social retfærdighed end på grund af organisationens terrorkrig imod Israel.

Palæstinenserne - eller deres to ledende politiske organisationer har så desværre også selv sat det demokratiske forspring, de har haft, over styr ved at kaste deres samfund ud i en lang, blodig og ødelæggende borgerkrig. At denne interne strid har svækket dem og undergravet deres forhandlingsposition over for Israel, får naturligvis mange palæstinensere til at påstå, at det i virkeligheden er Israel, der står bag splittelsen.

\section{Forspildte muligheder}

Palæstinenserne klager konstant over israelske regeringers manglende fleksibilitet i fredsprocessen og uvilje til at forstå de begrænsninger Det Palæstinensiske Selvstyre opererer under. Men palæstinenserne har også selv ladet en lang række muligheder gå sig forbi. Senest har Israels insisteren på at fortsætte byggerierne i de jødiske bosættelser på trods af USA's indsigelser skabt en helt usædvanlig kulde i det ellers varme forhold mellem Washington og Jerusalem. Det kunne palæstinenserne have udnyttet til at vise sig endnu mere forhandlings- og kompromisvillige. Men muligheden blev forspildt, fordi præsident Abbas troede, at han tværtimod kunne udnytte uenigheden til at stå endnu stejlere på sit krav om et totalt byggestop. Re- 
sultatet er, at han intet har at vise frem. Hverken byggestop eller forhandlingssejr.

Palæstinenserne - eller snarere nogle palæstinensere - har taget ved lære af andre arabiske unges taktik. De lært at bruge de sociale medier på internettet og mobiltelefonerne til at koordinere og kommunikere. Og de har også lært, at ikke-voldsmodstand imod veludrustede, regulære sikkerhedsstyrker er en sikker vinder i mediernes dækning, som kan bruges politisk.

Det palæstinenserne $i k k e$ har taget ved lære af fra Det Arabiske Forår er, at mens de andre arabiske unge har protesteret imod deres egne myndigheders onder og deres egne samfunds mangler, så bruger palæstinenserne stadigvæk ethvert våben til kampen imod israelerne og ikke til at få deres eget samfund renset ud.

De kunne have udnyttet muligheden til at kræve, at deres egen ledelse lever op til nogle mindstekrav om ordentlig regeringsførelse, respekt for loven, effektiv korruptionsbekæmpelse, at respektere menneskerettighederne og så videre. Den helt uvante selvkritik, vi så udspille sig $\mathrm{i}$ de andre arabiske samfund, har vi endnu ikke set blandt palæstinenserne. Selvom vi ved, at utilfredsheden og kritikken er der.

\section{Israel forstenet}

Situationen i Israel er ikke meget bedre. Her synes regeringen ligeså forstenet i et for længst forsvundet verdensbillede, uden evne til at fornemme, at verden - ikke mindst den arabiske - har ændret sig.

De arabiske lande har tilbudt Israel fred, anerkendelse og normalisering af forholdene til gengæld for en palæstinensisk stat på Vestbredden, i Gaza-striben og med Østjerusalem som hovedstad samt en "retfærdig løsning på det palæstinensiske flygtningeproblem". Det er en unik mulighed for en fredsløsning, som blev inkluderet i den såkaldte Køreplan for fred i Mellemøsten. Den chance har Benyamin Netanyahus højre-nationalistiske regering også ladet gå fra sig, fordi den prioriterer fortsatte byggerier i nogle ligegyldige bosættelser højere end en fredsaftale, der bygger på et territorielt kompromis.

Der er ikke mange iagttagere eller analytikere, der er i tvivl om, at når freden en gang kommer, kommer den til at tage udgangspunkt i den såkaldte Clinton-plan fra slutningen af 2000. Det er mere eller mindre også den, præsident Barack Obama henviser til, når han taler om en palæstinensisk stat efter 67-linjerne med mindre variationer. Derfor er det ikke længere spørgsmålet, om en sådan løsning kommer. Men mere om Israel får den trukket ned over hovedet, eller om det bliver en, Israel positivt forhandler sig frem til og dermed også får indflydelse på.

Den indflydelsesrige amerikanske New York Times-kommentator Tho- 
mas L. Friedman er citeret for at have sagt, at Israels premierminister Benyamin Netanyahu er som en mand, der er sprunget ud fra fyrretyvende etage og undervejs i det frie fald påstår, at alt er OK, fordi han ikke har mærket nogen smerte, fordi han endnu ikke har ramt jorden. Og det er en meget god analogi.

At Israel bliver nødt til at gennemføre drastiske ændringer af sin politik i forhold til palæstinenserne og fredsprocessen har været åbenbart længe - ikke blot på grund af Det Arabiske Forår.

Befolkningsudviklingen gør, at der nu er lige så mange palæstinensere, som der er jøder i området fra Jordanfloden til Middelhavet - de områder vi normalt omtaler som Israel og de besatte områder - Vestbredden og Gaza-striben. Alene derfor er Israels fremtid truet.

Israel bliver nødt til at finde ud af, hvordan det vil forholde sig til områderne og deres befolkning. Israel erkendte tidligt i landets historie, at de arabere, der ikke flygtede i 1948, måtte blive ligeberettigede borgere med stemmeret, med retten til egne politiske partier og til at stille op og blive valgt. Den samme ret bliver palæstinenserne i de besatte områder nødt til at få, hvis Israel ikke vil opgive områderne. Men sker det, kan palæstinenserne, fordi de snart er et flertal, stemme Hamas' Ismail Haniya eller en anden lignende islamist ind som landets premierminister, og dermed kan Israel næppe længere siges at være en jødisk stat. Vælger Israel for at undgå dette, at palæstinenserne ikke skal have demokratiske rettigheder, så kan Israel i længden ikke påstå at være en demokratisk stat.

Derfor synes Israels eneste alternativ på længere sigt, hvis israelerne, som meningsmålingerne viser, ønsker at forblive en jødisk og demokratisk stat, at være at trække sig ud af de besatte områder.

Det er faktisk i Israels interesse, at der etableres en palæstinensisk stat.

De arabiske lande - eller mange af dem i hvert fald - og også store dele af deres befolkninger har for længst accepteret Israels eksistens. Ikke af lyst, men fordi det er en realitet. Den palæstinensiske sag er ikke længere et semi-religiøst dogme i den arabiske politiske debat, og det giver en fleksibilitet og nogle løsningsmuligheder, som ikke var der tidligere.

\section{Arabisk isvinter?}

Det Arabiske Forår har allerede haft indflydelse på situationen mellem Israel og palæstinenserne. Hvordan afhænger af, hvordan 'foråret' udvikler sig. Går 'foråret' over i en dejlig 'sommer', eller kommer en arabisk 'isvinter'. Det er der endnu ikke nogen, der ved. Men går de arabiske omvæltninger godt, så afhænger påvirkningen på Israel-Palæstinakonflikten af, hvor konstruktivt parterne hver især vælger at bruge de erfarin- 
ger og udviklinger, der i denne tid kommer til dem fra deres nærmeste nabolag.

Vælger palæstinenserne at bruge læren fra Det Arabiske Forår som et våben imod Israel eller som et redskab til at skabe et bedre Palæstina med en ledelse, som bekymrer sig om sit eget folks velfærd? De unge demonstranter i nabolandene tror ikke længere på deres lederes propaganda om, at alt ondt skyldes fjender udefra. De ved, at problemet er deres eget, og de forsøger lige nu at løse det. Fremtiden handler ikke om at ødelægge et naboland, men om at bygge sit eget op.

Mange palæstinensere mener allerede, at et talentfuldt folk som dem selv fortjener og burde kunne kræve flere politiske alternativer end et korrupt og råddent Fatah på den ene side og et ubøjeligt, militant og islamistisk Hamas på den anden. Spørgsmålet er, om de går i gang med at skabe dette alternativ og opbygge et velfungerende samfund indefra, eller om de hellere vil slås med Israel militært og politisk som allerede $\mathrm{i}$ årtier.

Og vælger Israel at se ændringerne i de arabiske lande som en mulighed eller som en trussel? Som et udtryk for, at en ung arabisk genera- tion ønsker et frit, åbent, liberalt samfund i fremskridt som det israelske, og at den udvikling præsenterer en unik mulighed for Israel til at få fred og blive en del af regionen? Eller har Israel i den grad vænnet sig til at have diktatorer og autokrater som naboer, så regeringen i Jerusalem vælger sikkerheden bag mere panser og højere murer snarere end tager risikoen for at kunne få fred og få afsluttet krigstilstanden? Spørgsmålet er endnu en gang, om Israel prioriterer landområder og jødiske bosættelser højere end Israels egen fremtid som en jødisk og demokratisk stat?

Omvæltningerne præsenterer både palæstinenserne og israelerne for et utal af trusler, problemer, udfordringer og muligheder. Indtil videre er der ikke noget der tyder på, at nogen af dem har mod, dristighed eller visioner til at gøre op med den linje, de hver især hidtil har ført. Og når det så ender med at gå galt - hvad det sandsynligvis vil gøre, så vil de igen traditionen tro give hinanden skylden for at drømmene endnu en gang er bristet.

Steffen Jensen er journalist. Han har veret TV2's Mellemøstkorrespondent siden stationens start $i 1988$. 